\title{
FEDERAL TAXATION: EMPLOYER'S REIMBURSEMENT OF EMPLOYEE'S LOSS ON SALE OF HOME TREATED AS COMPENSATION
}

$\mathrm{I}_{\mathrm{N}}$ Bradley v. Commissioner, ${ }^{1}$ the taxpayer had been reimbursed by his employer for the loss he sustained on the sale of his home. ${ }^{2}$ The Court of Appeals for the Fourth Circuit held that the amount of the reimbursement should have been reported as compensation, rejecting the contention that the payment represented part of the amount realized from the sale of the house. ${ }^{3}$ In so doing, it affirmed the Tax Court's decision ${ }^{4}$ overruling the earlier case of Otto Sorg Schairer. ${ }^{6}$

The court's decision rests on the concept of income first formulated in Commissioner v. Glenshaw Glass Co. ${ }^{6}$ Prior to Glenshaw, income had been broadly defined as "gain derived from capital, from labor, or from both combined." 7 Although often found overly restrictive, ${ }^{8}$ this test was never fully abrogated until the Glenshaw decision. ${ }^{9}$ There the Supreme Court, on the ground that Congress

\footnotetext{
1324 F.2d 610 (4th Cir. 1963).

2 The employee was hired to work in Richmond, Virginia. His previous job was in Wilmington, Delaware. He was not immediately successful in selling his house at its estimated value so his family remained in Wilmington while he stayed in Richmond during the week. He commuted to Wilmington on the weekends. His employer guaranteed to make up any loss on the sale of the home to promote an early sale.

${ }^{3}$ If this contention had been accepted, Bradley would have had to pay no tax on the reimbursement because the sum of the reimbursement and the sale price did not exceed its adjusted basis. See INT. REv. CoDE of 1954, $\$$ 61 (a) (3), 1001 (a), 1001 (b), and 1011 .

49 T.C. 652 (1963).

- 9 T.C. 549 (1947).

348 U.S. 426 (1955).

'Stratton's Independence, Ltd. v. Howbert, 231 U.S. 399, 415 (1913). The Howbert Court was defining income in relation to the Corporation Excise Tax Act of 1909, ch. $6, \S 38,36$ Stat. 112. Horvever, this definition was reiterated by the Supreme Court in relation to the Revenue Act of 1913 , ch. 16, $\S \mathrm{II}(B), 38$ Stat. 167, which was the first revenue act to adopt the wording used in $\S 22$ (a) of the 1939 Code, under which the Glenshaw case arose. See Eisner v. Macomber, 252 U.S. 189, 207 (1920).

For extensive accounts of the history of court treatment of this definition, sce Libin and Haydon, Embezzled Funds as Taxable Income: A Study in Judicial Footwork, 61 Mich. L. Rev. 425 (1963); Wright, The Effect of the Source of Realized Benefits upon the Supreme Court's Concept of Taxable Receipts, 8 STAN. L. REv. 164 (1956).

${ }^{8}$ See Wright, supra note 7, at $180-83$ and cases cited therein.

- The Glenshaw abrogation of the old definition appears to be the result of a gradual evolution of thought rather than a startlingly new idea. See Wright, supra note 7 , at 201 .
} 
intended to "tax all gains except those specifically exempted,"10 discarded the old definition and formulated the policy that the income provisions of the Code are to be liberally construed.

The Bradley decision rests explicitly on the principles of two cases which are representative of the Glenshaw policy-Commis: sioner v. LoBue ${ }^{11}$ and Commissioner v. Duberstein. ${ }^{12}$ In deciding that the gains in controversy were taxable as ordinary income, the Supreme Court in these cases stated that a court must inquire into the substance of a transaction, the real motivation of the payment; rather than the form which it is given by the parties. ${ }^{13}$ More specifically, these decisions seem to stand for the proposition that any accretion of wealth is taxable as ordinary income if it is received for personal services. ${ }^{14}$ Put into practice, these principles demand that a broad scope be given to the income provisions of the Code!

In the LoBue case ${ }^{15}$ the taxpayer contended that the gains from the exercise of stock options given him by his employer were not taxable as ordinary income because the options were given to confer upon him a "proprietary interest" in the business. ${ }^{16}$ The Supreme Court rejected that argument and found the gains to be taxable as ordinary income because granting the stock options was a form of

10348 U.S. at 430 . Similar statements had been made in Supreme Court opinions prior to the Glenshaw decision. See Commissioner v. Jacobson, 336 U.S. 28, 49 (1949); Helvering v. Stockholms Enskilda Bank, 293 U.S. 84, 89 (1934). However, the Glen: shaw opinion was the first in which the Court appeared to have intended such a statement to be interpreted literally.

21351 U.S. 243 (1956).

28363 U.S. 278 (1960).

${ }^{23}$ This point was explicitly made in Duberstein where the Court said that the proper criterion for determining if a payment is income "is one that inquires what the hasic reason for his [the transferor's] conduct was in fact-the dominant reason that explains his action in making the transfer." 363 U.S. at 286. The LoBue Court followed a similar process in its decision. See 351 U.S. at 248.

14 This can readily be seen from an examination of the facts and holdings of the LoBue case, discussed in text accompanying note 15 infra, and of the Duberstein case, discussed at note 16 infra.

${ }^{28}$ In applying the principles of the LoBue and Duberstein cases to the Bradley case, discussion will be limited to LoBue. Although the principles of the two cases are equally applicable, LoBue is simpler to discuss because its facts more closely approximate those in Bradley.

16 351 U.S. at 245 . On the other hand, the Duberstein case did not involve an employer-employee relation. The taxpayer in that case had given a competitor some sales leads which were of no use to his own company but which helped the competitor. In appreciation the competitor gave a car to the taxpayer. Rejecting the contention that the car was a gift, the Court held that the value of the car must be included as gross income because the competitor's intent was compensatory rather than donative. 
compensation. ${ }^{17}$ For the same reason, the court in Bradley rejected the employee's argument that the payments involved represented part of the return from the sale of the house. ${ }^{18}$ Regardless of the formalities of the transactions, the courts in both the Bradley and LoBue cases recognized that the purpose of the benefits conferred was to encourage the employee to take a greater interest in his work. In this regard, the LoBue Court stated: "When assets are transferred by an employer to an employee to secure better services they are plainly compensation."19

The LoBue rationale demands the result reached by the Bradley court. The reimbursement of the loss on the sale of Bradley's house was admitted to have been made to enable Bradley to be more effective on the job. ${ }^{20}$ As such, the reimbursement was clearly compensation, regardless of the fact that the amount of the reimbursement was dependent upon the amount received by Bradley from the buyer.

The LoBue and Duberstein principles would also seem to have called for the overruling of the earlier Tax Court decision in Otto Sorg Schairer. ${ }^{21}$ There too the reimbursement of the employee's loss on the sale of his home was made so that he could be more effective on the job. ${ }^{22}$ However, Schairer was an existing employee

\footnotetext{
17351 U.S. at 248 .

${ }^{-18} 324$ F.2d at 612. The employee's argument here was not as specious as it may appear to be at first glance. Essentially, the employee was contending that the payment by the employer resulted from one transaction and should be viewed as a composite single payment representing return on the sale. This argument was accepted in three earlier cases. See David A. DeLong, 43 B.T.A. 1185 (1941) (sale of $X$ stock, receipt of $Y$ stock from one party and money from another); Cyrus S. Eaton, 37 B.T.A. 715 (1938) (purchase of stock at contract price, receipt of extra stock under different contract); James Brown, 10 B.T.A. 1036 (1928) (purchase of stock, receipt of money from third party).

The cited cases, however, were essentially different from the present case. In the cited cases, the extra benefits were offered at the same time that the transactions were conccived. The parties receiving the benefits did not initiate the transactions and entered them only because of the additional inducement. Therefore, the extra benefits did make up part of the consideration and the separate payments were actually part of one transaction.

10351 U.S. at 247.

${ }^{20}$ In explaining why Bradley's company offered to reimburse the loss on the sale of the house, the president of the company stated that Bradley was a key employce. "I felt that the fact that his family was in Wilmington and that he was going back and forth could have prevented his maximum contribution to the project. For that reason, I decided that it would be well to relieve his anxiety over the sales price of his home in Wilmington." Appendix to Brief for Petitioners, p. 14.

219 T.C. 549 (1947).

${ }^{22}$ Schairer had been employed by the company for many years when he was transferred to a new job location. The round trip from his old home to the new
} 
while Bradley was a new employee. ${ }^{23}$ Since there is ample authority for distinguishing between reimbursements made to existing employees and those made to new ones, ${ }^{24}$ the Bradley court could have distinguished the Schairer case on this ground.25

The position of the Internal Revenue Service regarding reimbursements for moving expenses is illustrative of that distinction. Although no moving expenses were deductible under the original 1954 Code ${ }^{26}$ the Service ruled that a reimbursement by an employer of the cost of transporting an existing employee's family and personal effects to a new job location can be excluded from the employee's reported gross income. ${ }^{27}$ Thus special treatment, which did not extend to new employees, is said to rest on the basis that such reimbursements are not compensatory when the move is made "primarily for the benefit of the employer." 28

Since all moving expenses are generically related, the distinctive treatment of some reimbursed moving expenses incurred by existing employees could have been extended to apply to the Bradley type of moving expense. ${ }^{29}$ However, the logic upon which that distinction

location and back required five hours and since his duties required him to be on call day and night, the company ordered him to move his home closer to the job, guaranteeing to reimburse him for any loss on the sale of the house. 9 T.C. at 550-51.

${ }^{23}$ The term "existing" or "old" employee will be used to describe a person who was employed by the reimbursing employer at both the old and new places of work. The term "new employee" will be used to describe someone who first enters the employment of the reimbursing employer at the new place of employment.

${ }^{24}$ See John E. Cavanagh, 36 T.C. 300 (1961) (reimbursement of old employee's moving expenses not taxable); Rev. Rul. 429, 1954-2 Cum. Bulx. 53. Compare United States v. Woodall, 255 F.2d 370 (10th Cir. 1958) (reimbursement of new employee's moving expenses taxable); Alan J. Vandermade, 36 T.C. 607 (1961) (reimbursement of new employee's moving expenses taxable).

${ }^{20}$ The government primarily contended for an overruling of the Schairer case. In the alternative it urged that that case was distinguishable. See Brief for Respondent, p. 7.

${ }^{20}$ Until this year, all moving expenses were considered to be personal expenses. See Treas. Reg. $\$ 1.262-1$ (b) (5) (1958). As such they were not deductible. INr. Rev. CoDE of 1954, $\S 262$. However, this is no longer true since the 1964 Revenue Act has amended the Code, providing for a deduction of such expenses. See INT. REv. CoDE of 1954, § 217, 78 Stat. 51 (1964).

${ }^{27}$ Rev. Rul. 429, 1954-2 Cum. Bull. 53.

28 Ibid.

${ }^{20}$ At least some expenses incidental to moving, although not included in the ruling's list, have been treated the same as those enumerated in Revenue Ruling 54-429. See John E. Cavanagh, 36 T.C. 300 (1961) (reimbursement of extraordinary living expenses at new residence). Some commentators also feel that many other moving expenses, including the loss on the sale of a house, can be treated the same way. See. Palley, Moving and Rearrangement Expense, 36 TAxEs 189 (1958); Tax Management, Inc., Moving Expenses, 6 Prac. LAw. 68 (May, 1960). 
is based is too weak to justify the distinction as applied within its present limits; much less does it justify an extension of the distinction beyond those limits. The argument that a reimbursement of an existing employee's moving expenses is not compensatory when the move is made primarily for the benefit of the employer seems unsound for two reasons. First, the test for application of the distinctive treatment is impractical and awkward. ${ }^{30}$ It seems unlikely that either the employer or the employee would be primarily benefitted by such a move. ${ }^{31}$ But even assuming that a situation did exist where an employer is primarily benefitted, the "benefit" that each derived could only be determined by weighing a great number of advantages and disadvantages, both tangible and intangible. ${ }^{32}$ Problems of proof would be difficult to overcome.

The second reason for the distinction's unsoundness lies in the LoBue and Duberstein principles. An examination of the possible motives $^{38}$ of an employer in reimbursing his employee's moving expenses can only lead to the conclusion that he is compensating the employee by making such a payment. ${ }^{34}$ Perhaps the employee would not have been willing to move without the employer's reimbursement, in which case the employer would make the payment in order to receive the employee's services where he wanted them. Or, per-

${ }^{20}$ Evidence of this fact can be found in the Service's treatment of such reimburscments. According to one author, the dearth of case authority in the area covered by the ruling is due to the fact that the Service accepts a move made by an existing employee as being primarily for his employer's benefit if the employec does not report a reimbursement of the moving expenses as income. Tax Management, Inc., supra note 29, at 71 . Hence, it seems that the test promulgated by the Service is not even being applied. This indicates that either the Service finds the test to be im. practical, or that it has decided that no existing employee should be required to pay taxes on such a reimbursement.

${ }^{81}$ Certainly an employer may benefit greatly by having a key man in the position where he is most needed. However, the moving employee will generally receive a reciprocal benefit in some form or another, such as an increased salary, higher job status, possibility of advancement, or job security.

${ }^{82}$ To determine how much benefit the employer gains, such factors as the importance of the employee's new position, the employee's expendability, and his salary would have to be taken into account. It would be even more complicated to determine the extent of benefit (or lack of it) derived by the employee. Such factors as the cost of living, raise in salary, personal taste in localities, and family ties would have to be considered. Then the benefits accruing to each would have to be weighed in order to reach a result.

${ }^{33}$ This is the method prescribed by the Supreme Court for determining whether a payment is compensatory. See note 13 supra and accompanying text.

si The only other alternative would be to conclude that the reimbursement is a gift. However, a gift is given because of "detached and disinterested gencrosity." Commissioner v. LoBue, 351 U.S. at 246 . It is highly unlikely that a court would find that motivation present in a transfer from an employer to an employee. 
haps the employer is attempting to build up good will by making the payment, in which case the payment would be made to procure better services from the employee. In any case, the LoBue and Duberstein principles demand that such a payment be viewed as compensatory. ${ }^{35}$ The fact that an existing employee is involved has no bearing on the issue-the employer's motives are determinative and they remain the same regardless of the tenure of the employee's employment.

The conclusion that the Bradley court properly overruled Schairer is reinforced by the committee reports on the new section $217^{36}$ of the Code. That section allows any employee, new or old, to deduct his moving expenses from gross income. ${ }^{37}$ The committee reports state that the reason for the new section is that the Service's special treatment of reimbursed moving expenses of existing employees is discriminatory and unreasonable..$^{38}$

Since employers do not frequently reimburse employees for losses sustained in the sale of their homes, the importance of the demise of the Schairer rule may appear to be relatively minor. However, the implication of the Bradley court's action in this regard is that the question of a payment being compensatory is not affected by the employee's tenure of employment. The real significance of the Bradley opinion lies in this implication. If fully developed, this aspect of the decision may be utilized in the future to further limit the scope of the distinction drawn between existing and new employees.

\footnotetext{
${ }^{85}$ See text accompanying notes $14 \& 19$ supra.

${ }^{30}$ INT. Rev. Code of 1954, $\$ 217,78$ Stat. 51 (1964). See note 26 supra.

${ }^{37}$ The new section himits the deductible moving expenses to those named in Revenue Ruling 54-429, viz., the cost of transporting the employee, his family and his household goods, together with the cost of meals and lodging en route. Of course, these expenses are not deductible if the employee takes advantage of the exclusion allowed in the ruling. INT. Rev. Code of 1954, $\$ 217$ (b) (1), (e), 78 Stat. 51 (1964).

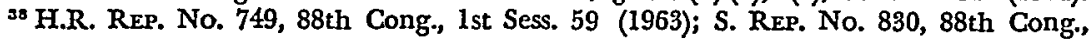
2d Sess. 71 (1964). Further, congressional approval of the Bradley decision might even be inferred from a different aspect of the proceedings on the new tax bill. The Senate committee reporting two months after the Bradley decision, amended the House recommendations (made before Bradley) by adding a new section which would have, in effect, reinstated the Schairer rule. See S. REP. No. 830, 88th Cong., 2d Sess. 129 (1964). This proposal, however, was discarded in the conference committee's final proposals. See CoNF. REP. No. 1149, 88th Cong., 2d Sess. 49 (1964).

It is interesting to note that the Senate committee apparently felt that the distinction between new and old employees was important in this area since they would have limited application of the new section to old employees. See S. REP. No. 830, 88th Cong., 2d Sess. 130 (1964). Yet, they had found the distinction to be unreasonable in regard to Revenue Ruling 54-429. See S. REP. No. 830, 88th Cong., 2d Sess. 71 (1964).
} 